\title{
Spirituality and practice of the euphemism in the workplace: perceptions of a nursing team
}

\author{
Espiritualidade e prática da eufemia no ambiente de trabalho: percepções de uma equipe de enfermagem \\ Espiritualidad y práctica de la eufemia en el lugar de trabajo: percepciones de un equipo de enfermería
}

Edilaine Maran'
ORCID: 0000-0001-6085-2692
Laura Misue Matsuda"'
ORCID: 0000-0002-4280-7203
Dandara Novakowski Spigolon'
ORCID: 0000-0002-9615-4420
Elen Ferraz Teston"'
ORCID: 0000-0001-6835-0574
Edna dos Santos Almeida'
ORCID: 0000-0002-4324-422X
Patrícia Amara da Silva'
ORCID: 0000-0002-0114-9195
Sonia Silva Marcon"
ORCID: 0000-0002-6607-362X

'Universidade Estadual do Paraná. Paranavaí, Paraná, Brazil. "Universidade Estadual de Maringá. Maringá, Paraná, Brazil. "'Universidade Federal do Mato Grosso do Sul. Campo Grande, Mato Grosso do Sul, Brazil.

How to cite this article: Maran E, Matsuda LM, Spigolon DN, Teston EF, Almeida ES, Silva PA, et al. Spirituality and practice of the euphemism in the workplace: perceptions of a nursing team. Rev Bras Enferm. 2020;73(Suppl 6):e20190707. doi: http://dx.doi.org/10.1590/0034-7167-2019-0707

\section{Corresponding author:}

Edilaine Maran

E-mail: edi_enf@hotmail.com

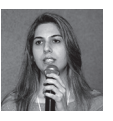

EDITOR IN CHIEF: Antonio José de Almeida Filho ASSOCIATE EDITOR: Mitzy Reichembach

\begin{abstract}
Objectives: to understand the spirituality and the practice of euphemism experienced by nursing professionals in the hospital scenario. Methods: a descriptive, exploratory research with a qualitative approach, carried out with 18 nursing professionals from a hospital in southern Brazil. Data collection took place from September to October 2018, through recorded audio interviews. The reports were submitted to thematic content analysis and the discussion was based on the theory of transpersonal care. Results: four categories emerged from the speeches: Motivational reflection of spirituality in the work environment; Adherence to the practice of euphemism by nursing professionals; Satisfaction and frustration in the practice of euphemism by nursing professionals and; Spirituality as an increase in human faith. Final Considerations: professionals understand spirituality and the practice of euphemism as a tool that helps in motivating the team to face difficulties at work and increase the faith of hospitalized patients.

Descriptors: Spirituality; Religion; Nursing; Working environment; Faith Healing.
\end{abstract}

\section{RESUMO}

Objetivos: compreender a espiritualidade e a prática da eufemia vivenciada por profissionais de enfermagem no contexto hospitalar. Métodos: pesquisa descritiva, exploratória, de abordagem qualitativa, desenvolvida com 18 profissionais de enfermagem de uma instituição hospitalar no Sul do Brasil. Os dados foram coletados no período de setembro a outubro de 2018, por meio de entrevistas áudio gravadas. Os relatos foram submetidos à análise de conteúdo temática e a discussão se fundamentou na teoria do cuidado transpessoal. Resultados: das falas emergiram quatro categorias: Reflexo motivacional da espiritualidade no ambiente de trabalho; Adesão à prática da eufemia por profissionais de enfermagem; Satisfação e frustração na prática da eufemia por profissionais de enfermagem e; Espiritualidade como incremento da fé humana. Considerações Finais: os profissionais percebem a espiritualidade e a prática da eufemia como ferramenta que auxilia a motivação da equipe para o enfrentamento das dificuldades no trabalho e no incremento da fé de pacientes hospitalizados.

Descritores: Espiritualidade; Oração; Enfermagem; Ambiente de Trabalho; Cura pela Fé.

\section{RESUMEN}

Objetivos: comprender la espiritualidad y la práctica de la eufemia que experimentan los profesionales de enfermería en el contexto hospitalario. Métodos: investigación exploratoria, descriptiva, cualitativa, desarrollada con 18 profesionales de enfermería de un hospital en el sur de Brasil. Los datos se recopilaron entre septiembre y octubre de 2018, a través de entrevistas de audio grabadas. Los informes fueron sometidos a análisis de contenido temático y la discusión se basó en la teoría del cuidado transpersonal. Resultados: de las declaraciones surgieron cuatro categorías: Reflexión motivacional de la espiritualidad en el ambiente de trabajo; Adhesión a la práctica de la eufemia por profesionales de enfermería; Satisfacción y frustración en la práctica de la eufemia por profesionales de enfermería; y La espiritualidad como un aumento en la fe humana. Consideraciones Finales: los profesionales perciben la espiritualidad y la práctica de la eufemia como una herramienta que ayuda a motivar al equipo, hacer frente a las dificultades en el trabajo y aumentar la fe de los pacientes hospitalizados. Descriptores: Espiritualidad; Religión; Enfermería; Ambiente de Trabajo; Curación por la Fe. 


\section{INTRODUCTION}

Spirituality in the organizational environment comprises three dimensions: self-immersion in work, interconnectivity and selffulfillment ${ }^{(1)}$. The first concerns the support offered by the organization for employees to experience aspects of their spirituality, aiming to increase their commitment, result and efficiency in the work environment; the second refers to the feeling of belonging to something much bigger than yourself in the organization and; finally, the third, self-fulfillment, which is associated with the level to which employees feel full or satisfied when going through experiences of mental and spiritual growth ${ }^{(1)}$.

Spirituality and religiosity are sometimes understood with the same semantics, but there is a difference between them because spirituality is related to one's existential dimension, by driving someone to the awareness of own moral context or not ${ }^{(2)}$, that is, spirituality consists in the personal search for answers about the meaning of life and the relationship with the Sacred and/or transcendent ${ }^{(3)}$. In this respect, spirituality may or may not be related to religious doctrine ${ }^{(2)}$.

Religiosity, in turn, presents itself as a quality of religion ${ }^{(3)}$. It is the connection between man and the divine, through an organized system of beliefs, practices and rituals performed by individuals who come together in search of the approach to the Sacred and/or transcendent ${ }^{(3)}$.

An important religious and spiritual experience is the search for God through euphemism: orate (supplication, invocation, communication, speech); petition (oral ritual, requests, pleas, instances) and; prayer (act of reciting or reading aloud) ${ }^{(4)}$. Despite the discreet dissemination in the scientific community, the term euphemism was used in this study because it encompasses the concepts of orate, petition and prayer, assumed as synonyms because they represent the search for God and divine intervention in petitions.

In the health field, the Spirituality/Religiosity (S/R) experienced in the work environment brings a sense of life and comfort amid human suffering that permeates the personal discovery of transcendence of the individual's health-disease state ${ }^{(2)}$. Spiritual/ theological reflections associated with spiritual practice at work favor the respectful relationship between professionals, better management of conflicts, humanized and satisfying care for patients ${ }^{(5)}$. This is because the interdisciplinary insertion of spiritual/theological issues in a clinical/therapeutic setting, empty of imposed religious traditions and dogmas, seems to strengthen the construction of professional "knowledge" that results in a rich performance in organizational work and in the whole dimension of the Human Being, consolidating the art of holistic health care.

In the 1990s, the World Health Organization (WHO) created an instrument that assesses people's quality of life ${ }^{(6)}$. Based on this, strategies were established to assist health promotion and quality of life ${ }^{(7)}$. Among the strategies, religious and spiritual experience, such as euphemism and meditations in health care, proved to be factors of longevity and physical, mental and spiritual well-being ${ }^{(7)}$.

In nursing, it appears that $S / R$ contributes to the promotion of the emotional comfort and well-being of those who care and those who are cared for ${ }^{(8)}$. In this regard, the theory of transpersonal care, created by Jean Watson, in 1988, is a model of assistance, based on humanistic and metaphysical concepts, which has a central focus on holistic care, which includes the physical, biological and spiritual dimensions. This theory intends to promote harmony between spirit, mind and body and thus reestablish human subjectivity, both for the patient and the nurse involved in the care process ${ }^{(9)}$.

Concerning the spiritual care offered in hospitals, it is a useful strategy to strengthen the nurse's commitment to providing comprehensive care, with the further concern of serving and respecting the patient's religious beliefs ${ }^{(7)}$. The appreciation of spirituality by nursing managers is the primary step towards the development of awareness and sensitivity to spiritual/religious issues in the art of care ${ }^{(10)}$, to overcome the reductionist belief that limits the patient to the physiological dimension. On the other hand, the insertion of $S / R$ is considered a challenge for the nursing team, because, since academic training, there is no preparation for this care practice ${ }^{(11)}$.

Still in the hospital scenario, the acknowledgment of the benefits of $S / R$ is evident, but, paradoxically, institutional support for the spiritual dimension seems to be elementary, as it is observed that it is little applied as a strategy for self-immersion at work, interconnectivity and fulfillment of nursing professionals. Thus, understanding the $S / R$ phenomenon in the work environment and in the care practice of the nursing team, where the workday is often hard and stressful, is justified because, according to the literature, the professional's spiritual experience, through euphemism, provides mechanisms, such as faith, in coping with hostile situations, in places with excessive pressure ${ }^{(12)}$.

Based on the above, this study has the following research question: In the organizational and care context for hospitalized patients, how are the spirituality and the euphemism perceived by nursing professionals, along the working day?

\section{OBJECTIVES}

To understand the spirituality and the practice of euphemism experienced by nursing professionals in the hospital scenario.

\section{METHODS}

\section{Ethical aspects}

For the development of this study, the ethical and legal aspects regulated by Resolution 466/2012 of the National Health Council were followed, and the project was approved by the Ethics Committee in Research with Human Beings of the participant institution. All participants signed the Informed Consent Form, and to guarantee their anonymity, the extracts of their speeches are identified with the letter "l" for the interviewee, followed by an Arabic number referring to the order in which the interviews were conducted. It is worth mentioning that, in this process, the non-identification of the participants was guaranteed.

\section{Theoretical-Methodological Framework}

To systematize and analyze the data, the content analysis technique was used, in the thematic modality ${ }^{(13)}$. The theoretical framework was based on Jean Watson's Transpersonal Human Care ${ }^{(9)}$. 


\section{Study design}

A descriptive study with a qualitative approach, based on the Theory of Transpersonal Human Care.

\section{Methodological procedures}

First, the hospital approved the research to be carried out with the professionals of the Nursing team. Afterward, the project was sent to the Research Ethics Committee Involving Human Beings for consideration and approval.

Data collection was carried out by the intentional choice of professionals, as practicing, or having practiced euphemism in the workplace was the eligibility criterion. For theparticipants' recruitment procedure, initial contact was established with the nursing supervisors from the clinical-surgical inpatient units of the hospital under study, to confirm whether the teams and the nursing professionals practiced the euphemism and who they were. After the identification of the sample of eligible individuals, a personal invitation was made, at first to professionals in the morning shift, and after to the workers from the afternoon.

\section{Setting}

The study scenario was a medium-sized hospital in a municipality in the southern region of Brazil. This hospital is a private, non-profit, philanthropic institution and benefiting from social and health assistance, which offers outpatient and inpatient service to private clients, insured by health plans and SUS. The beds are arranged in the varied hospitalization units: Unit A - serves female and male SUS patients; Unit B - intended for patients with a private health plan; Unit $C$ - designated for private patients and other health insurance; Unit D -serves male SUS patients; Pediatrics unit; Pre-delivery unit; Maternity unit; Emergency Room; Neonatal and pediatric ICU and; Adult ICU.

In about 2015, the nursing manager, with institutional support, proposed to the inpatient units the practice of collective and voluntary euphemism by nursing/health professionals at the beginning of the shift. However, due to the turnover of supervisors, this collective practice has become unstable and even absent, over time, in most units.

\section{Data source}

The study participants were 18 nursing team professionals (Nurses, Technicians and Nursing Assistants), who belonged to the institution's effective staff, worked in the morning and afternoon shifts, and had practiced or still practiced euphemism, individually or collectively, before and/or along with the shift. Workers who were on vacation or any other type of leave during the investigated period were excluded.

\section{Data collection and organization}

Data collection took place in the clinical-surgical inpatient units, at a previously scheduled time, in September and October 2018, through a semi-structured questionnaire (age, sex, marital status, schooling, religion, spiritual/religious practices) and audio-recorded interview, based on the guiding questions: Tell me about spirituality at your work; Tell me about the practice of prayer by nursing professionals in your work environment.

The interviews lasted an average of 15 minutes and were carried out by two researchers who had no relationship with the researched institution, in a private room. The inclusion of participants continued until the data saturation and the achievement of the objective was reached in the $18^{\text {th }}$ interview.

The interviews were recorded with the participants' previous authorization for later transcription. It is noteworthy that all interviews were transcribed in full, categorized from the first participant, by the two interviewers and, afterward, validated by the other researchers of this study.

\section{Data analysis}

The data analysis of the interview was based on the content analysis technique, in the thematic modality, following the stages of pre-analysis, material exploration, data treatment and inference of the results ${ }^{(13)}$. Four categories emerged from this process, and its discussion will be based mainly on the conceptual theoretical framework of Transpersonal Care, by Jean Watson ${ }^{(9)}$.

\section{RESULTS}

The 18 nursing professionals who participated in the study (16 Nursing Technicians, one Nurse and one Nursing Assistant), had a mean age of 29 years (minimum 18 and maximum 61 years). Of these, 17 were female, 11 declared themselves single, four married and three divorced. Regarding education, 14 had completed high school, and four had completed higher education.

Regarding religion, 15 expressed being catholic (eight lapsed Catholics), three evangelicals (one lapsed). Regarding the frequency the respondents pray, seven reported doing it once a day, two reported it two or more times a day, three once a week, four two or more times a week, and two, sometimes in a year. All of them reported believing in God, feeling His presence when they pray, or read the Bible, and having practiced, at some point, team euphemism at the beginning of their shift. Eight declared that, for now, they did not pray at any time at work, ten said they did it individually and, of these, five said they practiced team euphemism, but occasionally.

Because the specific level of the professionals in this study characterizes a Christian profile, the arguments and results assume a status consistent with the "Christian perspective" and will be discussed in the light of the theory of transpersonal care.

From the speeches, the following categories emerged: "Motivational reflection of spirituality in the work environment";"Adherence to the practice of euphemism by nursing professionals"; "Satisfaction and frustration in the practice of euphemism by nursing professionals" and; "Spirituality as an increase in human faith".

It is emphasized that the excerpts/extracts/fragments presented underwent minor corrections, without changing the meaning of the excerpts, and the slangs and repetition were suppressed. Finally, to facilitate the reader's understanding, words or terms were inserted in parentheses. 


\section{Motivational reflection of spirituality in the work environment}

Spirituality, although intrinsic to the human being ${ }^{(9)}$, when practiced through euphemism, seems to work as a motivational trigger for the nursing worker to face the challenges of working in the hospital environment.

[...] we go in, make a prayer and it seems that the day goes well. When you have no time, it seems that everything is wrong, and anything can go wrong. (14)

Because we work more blessed [when we pray before starting work]. [...] you do things with more affection and more love for others. (15)

[...] I have noticed that the day we pray, things go better and when we don't, something happens to get in the way [...]. (114)

Yes. Because you need to have a [spiritual] base, the person needs to have something to believe in and the company needs to motivate [its workers] regardless of religion to support our workday. (16)

The practice of prayer at the beginning of the shift, as a way of dealing with possible tribulations at work and providing personal well-being, was also reported.

I liked it [...] we always said a prayer, asked for our day to be better [...]. Each day, someone did the prayer [...]. I believe that this way, we started [the work shift] a little lighter. (I1)

[With prayer] we feel a little more peaceful, we feel calmer [...] the environment is more serene and tranquil. (18)

[...] because get more confident on what we are doing [...] it touches each other, feels that it is God, I think our area [Nursing] has a lot of God. I always pray before I start my job, I believe that nursing is a very divine profession. So, I think it's very important to pray before starting to work. (113)

The practice of euphemism was mentioned to improve the interpersonal relationship between professionals, impacting on the motivation to work as a team.

[...] when we start the day with a prayer, I feel stronger and I feel that the team is more connected. (14)

When I was on the morning staff, we prayed, because it was another nurse [...] everyone was more peaceful and the environment more relaxing to work. So, it was less stressful and getting along [with the team] was better. (I13)

[...] if we do it [prayer] as a team it is better, we become closer and when we see each other every day, we work better, more confident with everything and really feel the presence of God that day. So, it would be nice to do [prayers] every day. (I17)

Euphemism also emerged as a support for professionals to deal with work overload, with the complexity of care and with deaths.
It's very important [euphemism at work] because, like it or not, because it is a stressful environment [...] it ends up overloading us. (I3)

I believe [in euphemism] because here is a very stressful environment. Sometimes, due to the deaths. [...] yes, praying is important. (I10)

Yes, [euphemism] is very important because we are in an overloaded [work] environment and subjected to everything. (I17)

\section{Adherence to the practice of euphemism by nursing professionals}

Although all participants declared themselves to be Christians and have developed spirituality, inconstancy was observed in the practice of collective euphemism in the workplace.

[...] because it is a very busy unit, at the beginning when I started here, even though we had different religions, we used to pray [...]. (I1)

[...] we haven't done it lately! We even used to say a prayer [...] then we prayed in the morning, even if it was to say an Our Father. Someone used to say a quick prayer, but we haven't done it for a while. [...] there is a Bible there, sometimes, on the weekend, we go there and read [...], but other than that, it almost doesn't happen. (17)

[The prayer] is something that is left aside. Something we don't talk about much. Especially because we have differences [of religion] [...]. (18)

Even the individual euphemism, in the daily routine of the hospital unit, does not seem to occur assiduously.

No. The only thing I do when I get here, when going up the ramp, is the sign of the Cross, but that's it. Prayer, no. (17)

Hardly, [...] sometimes when I start the shift, I raise my thoughts and say some short prayers, but hardly in the middle of the shift I stop and pray [...]. I don't have much time. (18)

When I enter [in the hospital]. In the work environment, not necessarily a long prayer, but a wish for everything to work out and happen well. When I leave too, for deliverance or something like that. (I11)

The applicability of euphemism in daily life, with the patient, was not reported, however, statements about the importance of God and trust in him seems to permeate care.

Ah! Yes! I say to the patients, [...] whenever I leave the room I say: stay with God! [...] / think it helps the person to stay up higher. (114)

[...] because they are seriously ill I think that God must always be present in hard, easy and at all times. (I3)

Yes. Because the field we work in, needs God so much [...] the evaluations are as if the patient didn't have a chance to live, but then, comes the action of God and changes everything. So, that's when I say [...] and I believe a lot [in God]. (110) 


\section{Satisfaction and frustration in the practice of euphemism by nursing professionals}

The feeling of satisfaction and frustration is implicit in the excerpts, as some professionals emphasized that $S / R$ is essential to the Human Being and its absence causes an emotional gap. The excerptsthat support this testimony reveal an intrinsic cause-effect link in the work environment, according to the interviewees' perception:

[...] I feel the difference because when we did [prayers], we had the impression that things were resolved, the work would go well. Now that we don't [prayers] things seem to be tied up. [...] spirituality in the work environment makes a big difference for the team. (I3)

[Prayer] is needed. In our routine, in our personal life, in the work environment, I think we need to get a little more towards the religious side. I think that modern life keeps us away from that [of prayer]. It is a shame! (18)

[...] before, even if we're in a hurry. We went there in the utility room and did at least a quick prayer. At least, to cheer up a little. [...] everything starts with prayer and it should be like that, but because of the rush, we go in knowing that we have a lot of things to do and end up leaving it behind. Sad, is not it? (115)

\section{Spirituality as an increase in human faith}

The spiritual dimension evokes a condition inseparable from the physical and mental dimension of the human being, because, in the professionals' perception, spirituality produces benefits not only for the caregiver, but also for the patient.

[...] whatever type of spirituality, whenever you think about it, you think about kindness, putting yourself in the other's place and that is always an advantage for the patient [...]. I believe that the patient is greatly benefited when the person of any religion has this conduct [...]. (18)

Among the expressed benefits of $S / R$ in the management of negative feelings in hospitalized patients, the positive/optimistic response was the one that stood out the most.

Sometimes, there is a patient who is here alone, and that woman comes [from the prayer group] and prays for us, for the patient, for everyone and that is good. The patient gets uplifted. (14)

[...] you enter the room and the patient looks so melancholic, discouraged, afraid that nothing will come out right [...]. Then, you speak a word of God [...] the patient gets excited and we can see that. (114)

[...] dealing with health is not easy, they [the patients] are very fragile. Sometimes I see a patient and read the Bible [...] these days I took a Bible, opened it in a chapter and gave it to her [the patient] to read a chapter and left. Then I came back, and she was crying. She said that God used me to read that [...]. (I15)

[When I speak of God] they smile! They hug us [...] / say that, even if they are here, a God is watching over them. (I18)

\section{DISCUSSION}

In hospital institutions, there is constant stress, fear, and the risk of death. These factors result in an emotional burden on health professionals, patients, and family members, which must be managed and assisted ${ }^{(14)}$. However, if spirituality permeates the process of managing and assisting emotions, it can improve the levels of satisfaction of individuals who experience the nosocomial environment. This is because S/R provides harmony between body, mind, and soul, with a positive influence on the emotional balance of health professionals and patients ${ }^{(9)}$.

According to the excerpts presented, the practice of orating, petitioning, or saying prayers generates, in professionals and patients, well-being and support in the management of situations of suffering and pain that involve the health care process. Thus, reinforcing this opinion, some authors ${ }^{(8)}$ affirm that spirituality is additional care that Nursing can use, without restriction.

In Brazil, a study carried out in a philanthropic hospital with patients undergoing chemotherapy treatment revealed that prayer provides a new perspective for nursing care, as it is a care option that offers benefits to conventional treatment, besides meeting the spiritual dimension of inpatients ${ }^{(12)}$. In the same study, the authors state that a prayer is a tool that helps to cope with anxiety and illness and, therefore, can be considered a care strategy by Nursing ${ }^{(12)}$.

Through religion, some advantages can be stimulated, for example, tolerance, the acceptance of different situations, the promotion/valuation of ethical and moral principles, and also the improvement in relationships among professionals ${ }^{(15)}$. The aforementioned questions or virtues converge to the participants' statements (14, I13 and I17), who stated that, through the euphemism, there was an improvement in the interaction among the team members, corroborating what Watson exposes ${ }^{(9)}$ when he affirms that the respectful interpersonal relationship causes the dimensions of sense of being and harmony in the work team.

The aforementioned excerpts and others presented in this study confirm the literature ${ }^{(9,12)}$, in the sense that belief and faith among nursing professionals lead them to a growing spiritual development throughout life, in addition to providing balanced environments and harmonious relationships between people of different faiths.

In the hospital scenario, the literature ${ }^{(16)}$ points out that it is common for health professionals to feel physically and emotionally overwhelmed, due to complications in their work routine. This fact was also observed in the statement of I10. To minimize this condition, it is suggested to health managers to promote means for the development of $S / R$ in the hospital environment, as it promotes personal satisfaction, mental health and the high sense of Being ${ }^{(9)}$.

The little experience and practices of moments of prayer performed in the workplace are sometimes defined as a lack of opportunity to experience spiritual moments in a team ${ }^{(17)}$. This situation was observed in the statements of 17 and 18 , which showed the inconstancy of individual and collective euphemism in the workday. Thus, it is recommended to experience individual and collective S/R among health professionals, to encourage communication between the team and self-sufficiency in the work environment ${ }^{(1,9)}$, as long as individual, ethical- professional and institutional respect are ensured. 
The dualistic feeling between the satisfaction of the nursing team in the presence of euphemism, and frustration in its absence, during the workday, was found in the excerpts of 18,113 and I15. These feelings can be better understood in the light of the framework ${ }^{(9)}$ that guides this study and addresses that the harmony between mind, body and soul generates a feeling of consistency within the person and contributes to self-knowledge, self-respect, self-control, health and well-being. Disharmony and inconsistency lead to threat, anxiety, inner turbulence, existential despair, malaise, and fear ${ }^{(9)}$.

The spiritual dimension has been widely valued and recognized for its positive results in the workplace ${ }^{(1,9,12,18-20)}$. Despite this, it is observed that it is still a little-explored element as a healthcare practice, especially in the hospital environment. As reported in the literature ${ }^{(9,20)}$, if this practice is applied by health professionals, it can provide benefits to patients such as strength, tranquility and faith to face the disease and the treatment process, even in cases of incurable pathologies.

Although the practice of euphemism in dealing with the patient has not been observed, the fragments express the benefits of care centered on spirituality. These results corroborate the literature ${ }^{(9,18-20)}$ that reports the benefits on the patient's health status: relief of tension, increased feeling of hope and, especially, reduced anxiety. Also in this perspective, Watson ${ }^{(9)}$ highlights the importance of the nurse developing the patient's personal and spiritual potentialities, considering that this professional is an active participant in the care process and can promote benefits to that, such as the self-recovery of human integrity and harmony between who cares and who is cared for.

In the S/R scenario, seeking the applicability of holistic health care, it was proved, in a study ${ }^{(19)}$ carried out in Brazil, with chronic renal patients in a hospital, that the practice of euphemism promotes relief of the patient's suffering undergoing hemodialysis, besides improving vital sign values. Likewise, another study carried out in Iran revealed that the implementation of programs based on religious beliefs improved the quality of life, as it promoted hope in patients with heart failure, also beneficial effects on the physical and mental health of their families ${ }^{(20)}$.

A study carried out with 404 (90.8\%) North American nurses, estimates that the nurse's $S / R$ has an impact on nursing care when this professional does a spiritual or religious discourse congruent with the patient. Also, the study corroborates that professionals should not hold in their beliefs while providing care, as long as the spiritual care offered is respectful and ethical ${ }^{(21)}$.

The care associated with S/R was observed in a study ${ }^{(10)}$ developed with nurses from a hospital in Saudi Arabia, who recognized the importance of spiritual care for institutionalized patients, showing concern for the full well-being of the patient. With this, it is possible to observe that transpersonal care is filled in the act of understanding the comprehensiveness of the individual as mind, body and spirit, favoring the release of feelings that allow the patient to receive not only physical care, but the improvement in the condition of their Being ${ }^{(9)}$.

Caring involves getting to know oneself, getting to know the other, being compassionate, caring for people not only in life and death situations, but, above all, understanding the connections of the human being in their entirety, and all of this, surely, is related to transpersonal care that has the premise of intervening in a single Being, without dissociating the dimensions of its existence, whetherv physical, mental and/or spiritual ${ }^{(9)}$.

The health professionals' performance in comprehensive patient care can be influenced during their training, as many professionals do not feel prepared and qualified for the care practice that incorporates the spiritual dimension. In this regard, a study ${ }^{(22)}$ carried out with undergraduate students from the health area found that they were in favor of including themes on $\mathrm{S} / \mathrm{R}$, during the comprehensive health care classes, as part of professional training.

Given the above, it is considered that there are still gaps in the process of managing comprehensive care, especially in the current national curriculum structure, which limits the development of $S / R$ as a care strategy by nursing professionals in the face of unpreparedness for this practice since academic training, and this tends to weaken holistic care for hospitalized patients.

In this study, it is observed that nursing is based on one of the pillars of care: transpersonal care, which involves the binomial professional-patient, from the perspective of an ontological view with sensitivity for understanding the value of life that transcends the physical and mentalaspects, consolidating the praxis of taking care of oneself and the other, in professional practice.

\section{Limitations of the Study}

As a limitation of this study, the peculiar experience of the practice of euphemism stands out forbeing onlyone group of essentially Christian nursing professionals, from the day shift of a single hospital institution. Also, the study was not guided by the limits of the literature regarding ethics and patient-centered care, which the professional recognizes and ensures the patient's values and motivations for any spiritual practice. Thus, further studies that portray the problem of professional practice and the ethical dimension of how to deal with patients' spiritualityare suggested. It is suggested that other scenarios of the health care network be investigated, with different categories of workers and with methods that complement and deepen the knowledge about the phenomenon investigated, as is the case of the mixed research approach.

\section{Contributions to the Nursing field, health, and public policies}

This study proves to be relevant for nursing because the approach of care centered on spirituality/religiosity can arouse the need to implement health education strategies focused on this theme, as a feasible path for the commitment of the team, patients and family members based on a respectful and supportive organizational environment. The results obtained here also contribute to the value of strengthening teams, having euphemism and spirituality as mediators, because, according to the statement of the participants, the practice of euphemism is important for the teams'euthymia, to raise the condition of a particular mood, and also the clinical relationship.

\section{FINAL CONSIDERATIONS}

In this study, it was understood that nursing professionals perceive spirituality and the practice of euphemism as a motivational tool for the team, to face the difficulties experienced at work and to 
increase the faith of the hospitalized patient. Also, the inconsistency in the practice of euphemism in the daily work of the nursing team was mentioned as a reason that generates a feeling of satisfaction, in its presence, and of frustration, in its absence.

\section{FUNDING}

Research supported by the Fundação Araucária, according to notice 010/2018 - PRPPG/Unespar.

\section{REFERENCES}

1. Moore TW, Casper WJ. An examination of proxy measures of workplace spirituality: A profile model of multidimensional constructs. J Leadership Organ Stud. 2006;12(4):109-18. doi: 10.1177/107179190601200407

2. Souza W. A espiritualidade como fonte sistêmica na Bioética. Rev Pistis Prax, Teol Pastor [Internet]. 2013 [cited 2018 Jan 10];5(1):91-121. Available from: https://periodicos.pucpr.br/index.php/pistispraxis/article/view/8684/8357

3. Koenig H. Medicina, religião e saúde: o encontro da ciência e da espiritualidade. Porto Alegre: LMP, 2012. 248 p.

4. Cabral JP. A prece revisitada: comemorando a obra inacabada de Marcel. Mauss Relig Soc. 2009;29(2):13-28. doi: 10.1590/ S0100-85872009000200002

5. Gerone LGT. A religiosidade/espiritualidade na prática do cuidado entre profissionais da saúde. Rev Dossiê Espiritual Saúde [Internet]. 2016 [cited 2018 Jan 23];11(20):129-51. Available from: http://periodicos.pucminas.br/index.php/interacoes/article/ view/P.19832478.2016v11n20p129

6. World Health Organization. The WHOQOL Group. The World Health Organization Quality of Life assessment (WHOQOL): position paper from the World Health Organization. Soc Sci Med. 1995;41(10):1403-9. doi: 10.1016/0277-9536(95)00112-k

7. Moraes MRC. Reza para a vida longa: espiritualidade como fator de longevidade, segundo o noticiário. Rev Nures [Internet]. 2014 [cited 2018 Jun 20];27:1-8. Available from: https://revistas.pucsp.br/index.php/nures/article/view/25361

8. Tavares MM, Tosoli GM, Barbosa DJ, Cruz JC, Rocha BMM, Silva Thiengo PC. Spirituality and religiosity in the daily routine of Hospital nursing Rev Enferm UFPE. 2018;12(4):1097-102. doi: 10.5205/1981-8963-v12i4a235018p129-139-2018

9. Watson J. Human caring science: a theory of nursing. 2nd ed. Denver: Jones \& Bartlett Learning, 2012. 122 p.

10. Kaddourah B, Abu-Shaheen A, Al-Tanir M. Nurse's perceptions of spirituality and spiritual care at five tertiary care hospitais in Riyadh, Saudi Arabia: a cross-sectional study. Oman Med J. 2018;33(2):154-8. doi: 10.5001/omj.2018.28

11. Gulnar A, Wattis J, Snowden M., Rogers M. Spirituality in Nursing education: Knowledge and practice gaps. Int J Multidiscip Comp Stud [Internet]. 2018 [cited 2018 Jun 20];5(1-3):27-49. Available from: https://www.researchgate.net/ publication/329991452_Spirituality_in_Nursing_education_Knowledge_and_practice_gaps

12. Carvalho CC, Chaves ECL, lunes DH, Simão TP, Grasselli CSM, Braga CG. Effectiveness of prayer in reducing anxiety in cancer patients. Rev EsC Enferm. 2014;48(4):683-9. doi: 10.1590/S0080-623420140000400016

13. Bardin L. Análise de conteúdo. São Paulo: Edições 70, 2016. 141 p.

14. Mororó DDS, Enders BC, Lira ALBC, Silva CMB, Menezes MPR. Concept analysis of nursing care management in the hospital contexto. Acta Paul Enferm. 2017;30(3):323-32. doi: 10.1590/1982-0194201700043

15. Mesquita AC, Costa VAC, Neves BM, Alves ND, Souza TF, Cássia LCÉ. El bienestar espiritual y la prestación del cuidado espiritual en un equipo de enfermería. Index Enferm. 2014 ;23(4):219-23. doi: 10.4321/S1132-12962014000300006

16. Silva-Batalha EMS, Melleiro MM. Gestão hospitalar e cultura de segurança do paciente na percepção da equipe de enfermagem. Rev Baiana Saúde Pública. 2016;40(supl.1):109-23. doi: 10.22278/2318-2660.2016.v40.n0.a2670

17. Lavorato-Neto G, Rodrigues L, Turato ER, Campos CJC. The free spirit: spiritualism meanings by a Nursing team on psychiatry. Rev Bras Enferm. 2018;71(2):280-8. doi: 10.1590/0034-7167-2016-0428

18. Evangelista CB, Lopes MEL, Costa SFG, Abrão FMS, Batista PSS, Oliveira RC. Spirituality in patient care under palliative care: a study with nurses. Esc Anna Nery. 2016;20(1):176-82. doi: 10.5935/1414-8145.20160023

19. Brasileiro TOZ, Prado AAO, Assis BB, Nogueira DA, Lima RS, Chaves ECL. Effects of prayer on the vital signs of patients with chronic kidney disease: randomized controlled trial. Rev Esc Enferm USP. 2017;51:e03236. doi: 10.1590/S1980-220X2016024603236

20. Binaei N, Moeini M, Sadeghi M, Najafi M, Mohagheghia Z. Effects of hope promoting interventions based on religious beliefs on quality of life of patients with congestive heart failure and their families. Iran J Nurs Midwifery Res. 2016;21(1):77-83. doi: 10.4103/1735-9066.174755

21. Taylor EJ, Gober-Park C, Schoonover-Shoffner K, Mamier I, Somaiya CK, Bahjri K. Nurse opinions about initiating spiritual conversation and prayer in patient care. J Adv Nurs. 2018;74(10):2381-92. doi: 10.1111/jan.13777

22. Zanettil GC, Lemos GL, Gotti ES, Tomé JM, Silva AP, Rezende EAMR. Percepção de Acadêmicos de Medicina e de Outras Áreas da Saúde e Humanas (Ligadas à Saúde) sobre as Relações entre Espiritualidade, Religiosidade e Saúde. Rev Bras Educ Méd. 42(1):65-72;2018. doi: 10.1590/1981-52712018v42n1RB20160044 